\title{
Analysis Earning Management Practice: Approach Discretionary Loss Loan Provision (Case Study of Islamic Banks di Indonesia tahun 2011- 2016)
}

\author{
Ahmad Zaenal Ilham ${ }^{1 *}$, Wiwik Utami ${ }^{2}$ \\ ${ }^{1}$ Magister Akutansi, Mercubuana University Jakarta \\ ${ }^{2}$ Jl. Meruya Selatan No.1, Kembangan, Daerah Khusus Ibukota Jakarta
}

DOI: $10.36348 / \mathrm{sb} .2020 . v 06 i 01.004 \quad$ | Received: 17.01 .2020 | Accepted: 24.01.2020 | Published: 29.01.2020

*Corresponding author: Ahmad Zaenal Ilham

\section{Abstract}

The purpose of the study is to analysis wheter management did Earning Management with approach discretionary loss loan provision and use 5 indicator of bank operation performance at bank sharia for the period $2011-2016$. Based on empirical result from the bank sharia financial report, the study find: (1) the two earnings-related variables, namely earnings before loan loss provisions and one-year-ahead earnings, are significantly related to discretionary loan loss provision; (2) non-performing loans ratio is are not found to be significantly linked to discretionary loan loss provisions, but bad debts coverage ratio and capital adeuqcy ratio are significantly linked to discretionary loan loss provisions. Finally, our findings indicate that bank managers may use discretionary loan loss provisions to engage in earnings management when the earnings before loan loss provisions.

Keywords: Discretionary Loss Loan Provision, Earning Before Loss Loan provision, Earning One Year a Head, Capital Adequacy Ratio, Non-Performing Loan Ratio, Bad Debt Coverage Ratio, Sharia Banking.

Copyright @ 2020: This is an open-access article distributed under the terms of the Creative Commons Attribution license which permits unrestricted use, distribution, and reproduction in any medium for non-commercial use (NonCommercial, or CC-BY-NC) provided the original author and source are credited.

\section{Preliminary}

Technical accrual is the difference between profit and cash. The definition of accruals itself is a little difficult to find, because profit itself is only technically defined in accounting standards, namely as a result of income minus costs. Accrual occurs when transactions are recorded in books when they occur, even if payments for a particular product or service have not been received or made, it is known as accrualbased accounting. This method is more appropriate in assessing the health of an organization in financial terms.

Accruals arise due to accounting rules such as depreciation, loss reserves and so on. The decision regarding accounting rules is of course made by management. If the accrual policy is decided by management, there are terms Discretionary and NonDiscretionary.

Accrual accounting systems provide opportunities for management to manipulate earnings or accounting income $[1,2]$. Accrual accounting is divided into two concepts, namely Discretionary Accrual and Non-discretionary accruals. The concept of discretionary accruals means that management can manipulate income accruals and is usually used to achieve the desired income. De Angelo [1] in a previous study found that managers have the ability to control the accrual portion in the short term and also find that the Non-discretinary accruals component is determined by other factors that cannot be controlled by the manager.

Discretionary Accruals are accounting data manipulations called abnormal accruals. Discretionary accruals are accrual components derived from earning management by managers. Discretionary accruals cannot be observed directly from financial statements, they must be estimated through several models. The model forms expectations on the level of nondiscretionary accruals and the actual number of deviations observed, this is assumed to be nondiscretionary accruals. So that discretionary accruals are defined as accruals through the models used. In this 
study the model used to detect discretionary accruals with the McNichols and Wilson [3] model uses the estimated remaining regression model of uncollectible accounts in lieu of discretionary accruals.

Previous research conducted by Ahmed et al. [4] provide strong support for the hypothesis that loan loan provisions are used for earnings management and find there is a positive relationship between Income Before Losing Loans Provisioning and Giving Discretionary Losses. However, contrary to the results of the research found, in the results of the study it was found that there was no significant relationship between Income before Lending and Provision of Loans Discretionary Losses. However, in another study conducted by Chang et al. [5]. Finding positive results from the provision of credit before loss and giving credit loss discretionary. And I suggest that bank managers need to increase the allowance for accounts receivable to reduce bad credit and of course it will reduce the ratio of non-performing loans.

Furthermore [4] did not provide evidence of Profit Management through Allowance for Discretionary Loan Disposal. In his research it was found that Allowance for Discretionary Loan Losses is negatively related to changes in future income and ongoing stock returns. Furthermore, the literature provides different results regarding the relationship between credit and future loans, [6] regarding the relationship between Discretionary Loss of Provisional Loans and Future One-Year Income and finds a positive relationship between Discretionary Loss Loans and Earning One Year Future and higher one-year income is related to the level of loan disbursement this year.

Likewise, Niswander and Swanson [7], using call report data, financial reporting the Loan Provision portion was approved by the level of bank capital, income, and tax. In a sample of 11,000 banks, they show that banks below the capital adequacy threshold often make discretionary choices that reduce income and capital. Banks above the discretionary threshold are different, with evidence of income smoothing and tax benefits.

In a previous study conducted by Khotari et al. [8] make measurements that are more specific and powerful than other measurements of Discretionary accruals. Khotari [9] found that Performance Matching was designed to control the impact of performance in measuring Discretionary accruals and performance matched discretionary accruals and could be used as an alternative that could be used in researching earnings management. By referring to research conducted by Khotari et al. [9]. In this study researchers used 5 bank operating performance indicators, namely: Earning before Provison Loss Loan, Earning One Year ahead, Capital Adequacy Ratio, Non-Performing Loan Ratio and Bad Debt Coverage Ratio in measuring the Discretionary Loss Loan Provision.

\section{STUDY OF LITERATURE}

Sharia Enterprise Theory (SET) emphasizes God as its center; the emphasis in Islam is that economic growth must lead to social justice and a fairer distribution of power and wealth. The concept of Islam is brotherhood, equality and justice implies redistribution and transfer of resources between various groups in society [10].

A value-added statement shows how the company's benefits in an effort to gather employees, shareholders, the government and the company itself, may be very useful for Muslims. The distribution of wealth among various sectors of society, by definition, is a social interest issue and this is a characteristic of value added statements that support accountability in Islam. So, the statement of value added can be considered in accordance with the concept of justice and cooperation which actually spreads the characteristics of Islam itself compared to the income statement [11].

Enterprise Sharia Theory (SET) by Iwan Triyuwono [12] was developed based on the metaphor of the character of zakat balance In Islamic sharia; balance in concrete form is realized in the form of worship, namely zakat. Zakat (which later becomes the metaphor of zakat) implicitly contains egoistic altruistic values, spiritual material, and individual worshipers.

Furthermore the concept of SET is very different from ET which places humans - in this case shareholders - as a center in this context that welfare is concentrated in shareholders. Shariah Enterprise Theory is also different from Enterprise Theory even though the stakeholders are wider than Enterprise Theory, but stakeholders here remain in the human sense as the center.

Accounting must be viewed from a broader perspective or within the framework of postmodernism. The essence of accounting as a tool to produce an accountability report is certainly not only limited to the relationship between the agent and the principal (economy). Far from that, accounting is also a tool for accountability between investors with their social elements, their environment, and most importantly with their creators. The order to do accounting records was there at the time of the Prophet receiving revelations from God and even in the days of previous prophets because Islam was a religion of perfection. The relation between accounting and religion seen from any side has a very significant relationship. This linkage is not in the context of causality, or correlational, but in an emulsion where accounting is part of religion [13]. 
Accounting standards in Indonesia are still guided by pro-western accounting. All accounting standards are anchored on the theoretical foundation and accounting technology of IASC (International Accounting Standards Committee). Indonesia even openly realized at the IASC Frame Work for the Preparation and Presentation of Financial Statements, with the title of the Basic Framework for Preparation and Presentation of Financial Statements in Financial Accounting Standards (SAK) issued by the Indonesian Institute of Accountants (IAI). The latest development now has been socialized "new" accounting education system that refers to the internationalization and harmonization of accounting standards. Meetings, workshops, workshops, seminars on change [10].

In fact, countries that develop international accounting standards actually have trade dependence with the United States. Consequently, these countries must prepare their accounting systems according to the Acceptable General Accounting Guidelines in the United States (US GAAP). This dependence also has an impact on the acceptance of US GAAP not only in the United States but also in other countries that are associated with it. The United States is a country that is economically strong and large in the world and its ability to control most of its capital markets is very strong against changes in the IASB. The impact is clear, IAS (International Accounting Standards) cannot be adopted without the approval of the FASB (Financial Accounting Standard Boards) from the United States. The form of US involvement referred to by Merino et al. [8] as MNC's Setting Agenda) through harmonization for the benefit of MNC's. How then do accounting interventions through harmonization take place in Indonesia? Graham and Neu [14] detect it by what they call policy flows. The flow of policy in Indonesia was carried out after experiencing the 1997 financial crisis through the IMF (International Monetary Fund). The IMF proposes several conditions for lending conditionalities from the Memorandum of Economic and Financial Policies if it wants Indonesia's macroeconomic changes. One of the conditions is that accounting practices in Indonesia must conform and adopt the Neo-Liberal financial policies made by the IASB.

The pressure of political economy shows how the function of accounting as a technology of control is over information for centralized calculations and preconditions of covert subordinated interventions. Even the conclusion of the search for accounting and globalization from Graham and Neu [14] is that accounting organizations and technology are actually not only directed towards two memorandums of understanding signed between the IMF and the Indonesian government in 1997 before President Soeharto stepped down from the 1998 reform. Asymmetry and imbalance across international borders, but furthermore actually accounting is not neutral to serve salient liberalization especially for MNC's through its international institutions (such as the IMF, IASB, World Bank and others) for the flow of capital, products, information, policies and people. The end is the certainty of cash flow both in the form of bottom /profit and real in the form of increased equity for the owners of multinational companies.

Loss Loan Provision is a fee set aside as an allowance for loan losses and loan payments. This provision is used to cover a number of factors related to potential loan losses including bad credit, customer defaults and maturity renegotiation requirements lower than previously estimated payments. The provision for loss due to loans is an adjustment to the loan loss reserves and can be known as valuation allowances.

According to IAS30 and IAS43, banks are required to provide detailed information about loan losses. This information covers the method, terms and disadvantages of uncollectible loans, transfers in the framework of the allowance during the period covered by the financial statements (additional, write off uncollectible loans and Write Off collections and the total allowance for balance sheet dates [15]. In other words, very specific information about loan losses is required under IFRS, also with regard to individual loan classes, not aggregate amounts.

On the other hand, the provisions of loan losses will be a less effective tool for earnings management by bank management, according to [16], for conditions in Spain. They tested earnings management in banks in Spain, which had a very strict set of rules governing Loss Loan Provision and found that even so, management used a Loss Loan Provision for earnings management. They concluded that the adoption of IFRS was a step forward towards a principle-based approach, which might be the only remaining option for accounting standard makers to fight management using Loss Loan Provision for their policies. More detailed disclosures may be used to achieve management goals [16].

With this study, researchers hope to find an increase in disclosure of the Loss Loan Provision under IFRS which has led to fewer earnings management by banks, due to the relationship between the level of the Discretionary Loss Loan Provision and earnings management.

In the process of preparing financial statements, management often intervenes in the process of preparing financial statements, this is done because management has several motivations for this, including so that profits look good or stable, thereby increasing the value of the company and ultimately attracting investors. The actions taken by management are known 
as earnings management. This is supported by several theories that strengthen the notion of earnings management. Scott [17] defines earnings management as "the choice of manager of accounting policies or action affecting, so as to achieve some specific objective" statement explains that earnings management is the choice made by managers in choosing accounting policies or actions that can affect earnings, which aims to achieve several goals in reporting earnings.

Healy [18], shows how large and small an executive bonus package encourages managers to make discretionary accounting in a strategic way. Therefore, determining a minimum level compensation compensation contract to provide bonuses and incentives to increase income or decrease earnings management income depends on the actual level of profit achieved in a certain period.

Healy [18] uses accruals and changes in accounting procedures and finds that managers choose to increase accrual income as long as profit falls within the minimum and maximum limits. However, managers also tend to move towards decreasing accrual income if income is above the maximum level.

Performance is a basic concept that is general in nature. This concept is usually understood implicitly so that it is difficult to express explicitly. Performance related to certain concepts gives birth to specific approaches or measurements [19, 20]. Performance is also interpreted as a record of outcomes resulting from the function of a particular job or activity during a certain period.

Based on Bank Indonesia Circular Number 6/23 / DPNP dated 31 May 2004 concerning the Rating System for Commercial Banks, financial performance is measured using key financial ratio criteria, consisting of: 1) Problematic Earning Assets, 2) Non Performing Loans ( NPLs) -Gross); 3) Non Performing Loans (NPLs) - Net, 4) Ratio of Allowance for Earning Assets (PPAP) to Earning Assets; 5) Level of Adequacy of Allowance for Earning Assets (PPAP); 6) Return On Assets (ROA); 7) Return On Equity (ROE); 8) Net Interest Margin (NIM); 9) Operational Cost Ratio to Operating Income (BOPO); 10) Liquid Asset Ratio to Liquid Liabilities (ALPL); 11) Minimum Statutory Reserves (GWM) Ratio.

Discretionary accrual of loan loss provision is influenced by Earning before Loss Loan Provision; Academics often use agency theory as explaining earnings management habits. Agency theory clarifies contractual relationships between management (agents) and shareholders (principals). If both principals and agents act to maximize their own utility, behind a contractual relationship, management (agents) may not always act best in the interests of the shareholders (principals). This difference in importance between the two is due to agency problems [21]. From the point of view of some experts, asset abuse is an extreme result of agency problems. In the case of misuse of assets, managers infuse company assets for their own wealth at shareholder costs.

Wang [22] describes the problem of external agencies between founding families, managers and outside shareholders as "effect entrenchment" (entrenchment effect). Demirkan et al. [23] presents evidence that multi-segment companies experience poor quality Discretionary Accrual because more severe agency problems, companies that have multi segments are worse than single-segmented companies in the quality of Discretianary Accrual.

In a previous study conducted by Chang et al. [6] conducted a study to find out whether there was Earning Management using the Discertionary Loss Loan Provision with the approach of 5 banking performance indicators, one of which was Earning Before Loss Loan Provision. Furthermore, from the results of the study found there is a positive relationship between Earning before Loss Loan Provision and the Discretionary Loss Loan Provision and it suggests that bank managers tend to increase the provision of loss of accounts receivable to reduce bad credit and reduce Non Performing Loans.

Discretionary accrual for loan loss provision is Influenced by One Year ahead Earning, Provision of loan losses in the banking industry is mainly based on regulatory requirements in Indonesia and globally. In accordance with relative regulations, bank managers must classify loans into five categories based on risk assessment, and then use a predetermined proportion to calculate the amount of provision for potential loan losses per month. Ceteris paribus, after the bank manager decided to increase the amount of the loan loss requirement substantially in the current year, means that the number of loan loss provisions is likely to decrease significantly and cause an increase in profits next year. Wahlen [18] shows that when the prospect of future cash flows increases, bank managers can increase the discretionary component of unexpected loan loss provisions. They find a positive relationship between unexpected annual provisions and future changes in cash flows over the next three years. Beaver and Engel [24] adopted the concept of motivation signaling and followed Wahlen [18] to combine the next one year and the next two years of income in the model to estimate the discretionary portion of the allowance account. They see free allowances as a signal for a better future income and expect a positive relationship between them. But Ahmed et al. [4] do not provide evidence of earnings management through provisions for losing loans. They found that the loan loss provisions were negatively related to changes in future earnings and 
contemporary stock returns. Because the literature provides different results regarding the relationship between loan loss and income provisions in the future, researchers examine the relationship between future earnings and loan loss provisions and hope that higher next year's earnings are associated with higher loan losses this year.

Furthermore [6] examines the relationship between future annual earnings provisions and receivable losses and estimates that higher next year's income is related to the high level of loan allowance for this year.

Discretionary accrual on loan loss provisions is influenced by Capital Ratio, according to the Basel Capital Accord, capital ratios are calculated using the definition of capital and risk-weighted assets and are used by regulators to measure bank capital adequacy. The capital ratio is not lower than $8 \%$ [25]. One of the goals of banks managing capital is to maintain the capital ratio above at least $8 \%$. The authorities will limit bank activity when the capital ratio does not reach the drinking requirements. Thus, an inadequate capital ratio will bring banks that do not need to control costs [26] found that bank managers intend to choose accounting procedures to increase capital ratios to avoid additional control costs [27] provide evidence of the existence of a negative relationship between the provisions of loss of accounts receivable and capital ratios. [25] Estimates that the calculation of primary capital ratios shows that capital is added by increasing the provisions of losses and or decreasing borrowing costs, but empirically, banks with low capital seem to reduce the discretionary loan loss provisions to consider the capital ratio. Because the capital ratio plays an important role as an indicator to reflect the bank's risk status, this shows the bank's ability to survive in the current capital structure and implies a risk of default that is not visible [28] referring to the study [29] and showing an inadequate capital ratio to banks can use the discretionary loan loss provisions to increase the capital ratio. Although [4] suggests that after implementing the new Basel Capital Accord, the negative relationship between the provisions of losses and capital management has decreased [28] document that commercial banks are still utilizing loan loss provisions to influence capital and increase capital ratios.

Discretionary accrual over loan loss provision is influenced by Non-Performing Loan Ratio, Given the long-term performance, bank managers may prefer to increase the discretionary reduction loan terms in order to improve asset quality and reduce the ratio of non-performing loans in the future. They may sacrifice this year's income to be exchanged for better performance next year, if they expect that they cannot reach their goals this year. But given the short performance, bank managers can be forced to reduce loan terms because of compensation plans and work preservation motivation. Namely, managers will overestimate reported income or minimize negative net income. Therefore, the magnitude of the provisions for reducing free loans can be influenced by several key indicators with regard to performance measurement. The researcher hopes that the amount and ratio of bad loans can affect the manager's desire to increase or decrease the loan loss provisions.

The level of the ratio of non-performing loans shows the general quality of the loan portfolio. The downward trend in the ratio of non-performing loans means that the quality of total credit has improved and vice versa. Because the ratio of non-performing loans is calculated by dividing non-performing loans with total credit, the ratio of high non-performing loans means that the relatively large number of interests and principals cannot be collected.

Previous research conducted by a study conducted by Chang et al. [30] found a positive relationship between the Discretionary Loss Loan Provision and the Non-Performance Loan and it suggested that managers might increase Loss Loan Provision for the purpose of reducing Non-performing Loan Ratio.

Discretionary accrual of loan loss provision is influenced by Bad Debt Coverage Ratio, In addition to the ratio of bad loans, another ratio, which is the ratio of bad debt coverage, shows the proportion of allowance for bad debts in the potential for uncollectible loans. When the ratio of bad credit coverage reaches $100 \%$, it means the bank is ready for all loans that cannot be collected. After a potential uncollectible loan has been established as a "real" bad debt, the bank will clear its bad debt. Because the level of the ratio of uncollectible accounts reflects the attitude of bank managers to risk, banks with a higher ratio of uncollectible receivables remain the same policy for loans that cannot be collected.

Beatty et al. [27] provide evidence of a negative relationship between the provisions of loss of accounts receivable and capital ratios [25] estimates that the calculation of primary capital ratios shows that capital is added by increasing the provisions of losses and or decreasing borrowing costs, but empirically, banks with low capital seem to reduce the discretionary loan loss provisions to consider the capital ratio. Because the capital ratio plays an important role as an indicator to reflect the risk status of the bank, this shows the ability of the bank to survive in the current capital structure and implies an invisible risk of default [28] referring to the study [29] and showing an inadequate capital ratio to banks can use the discretionary loan loss provisions to increase the capital ratio. 
Although [4] suggests that after implementing the new Basel Capital Accord, the negative relationship between loss provisions and capital management has decreased [28] document that commercial banks are still utilizing loan loss provisions to influence capital and increase capital ratios.

\section{METHODOLOGHY}

The type of research used in this study is causality research, which is a type of research that aims to test hypotheses about the influence of one or several variables, the type of relationship that is arranged to examine the causal relationship between variables [31]. The variables used in this study include: 1) the independent variable is the allowance for losses and 2) the dependent variable is earnings management.

And the purpose of this study is to test whether earnings management practices in Islamic banking occurred in 2011-2016 with a proxy for loss allowance for discretionary accounts with 5 bank operating performance indicators, namely: Earning before Loss Loan Provison, One Year ahead Earning, Capital Adequacy Ratio, Non-Performing Loan Ratio and Bad Debt Coverage Ratio. Furthermore, all are awaited by using SPSS25 software.

McNichols and Wilson [3] used the estimation of the remaining regression models of uncollectible accounts in lieu of discretionary accruals. Provisions for loan losses are equal to the total balance of the allowance for uncollectible accounts and loan bills, and then reduce the initial balance of allowance for uncollectible accounts.

In practice, most bank managers decide on the number of loan loss provisions each month in accordance with an individual risk assessment of the possibility of removing uncollectible loans. Thus, the researcher uses the following regression to estimate loan loss provisions and treat regression residuals as a discretionary loan loss provision:

$$
\begin{aligned}
& L L P t=\beta 0+\beta 1 C O t+\beta 2 B \_B A L t+\varepsilon t(1) \\
& \text { LLPt : Loss Loan Provision year } \mathrm{t} \\
& \text { COt : Charge Off year } \mathrm{t} \\
& \text { B_BALt : Beginning Balance Loss Loan Provision } \\
& \text { Et : residual } \\
& \text { T : Year }
\end{aligned}
$$

In the event that the discretionary provisions for the allowance for losses are not directly observable, it is estimated by negotiating the loan loss provisions in the explanatory variable in Islamic Banking. The residuals of the equation are considered as estimates of the discretionary provisions for the allowance for accounts receivable. The researcher lowered the explanation variable, namely earning before Provison Loss Loan, One Year ahead Earning, Non-Performing Loan Ratio, bad debt coverage ratio and Capital Adequacy Ratio, and tested the hypothesis by estimating the coefficients of the following models:

$D L L P t=\gamma 0+\gamma 1 B P_{-} E A R N t+\gamma 2 E A R N t+1+\gamma 3 B I S t+\gamma 4 R_{-} N P L t t+\gamma 5 R_{-} C O V E R t+\varepsilon t(2)$

Where:

DLLPt : Discretionary Loss Loan Provision in year t

BP_EARNt : Earning Before Loss Loan Provision in the end of the year

EARNt+1 : Earning One Year A head in year $+1 \mathrm{t}$

BISt : Capital Ratio in the end of the year $\mathrm{t}$

R_NPLt : Non Performing Loan Ratio in the end of the year $\mathrm{t}$

R_COVERt $\quad$ : Bad Debt Coverage Ratio

The researcher followed [6] using the discretionary loss loan as a response variable to test the hypothesis. The six explanatory variables are equated, namely BP_EARNt, EARNt + R_NPLt, and $\mathrm{R}$ COVERt added to the model to test the researcher's hypothesis. BP_EARN is equal to bank income before the allowance for loan losses at the end of the year. The researcher calculates BP_EARNt by summing the loan loss provisions and pre-tax profits, and dividing the loan loss provisions at the end of the year with the number of non-performing loans to calculate R_COVERt. Like EARNt + 1, NPLt and R_NPLt, they are collected directly from the database on each Islamic banking website. In addition, researchers include several factors to tend to affect the bank's discretionary loan loss provisions.

Samples are a portion of the population. The sample consists of a number of selected members of the population. In other words, a number but not all, the sample in this study is the General Syariah Bank in Indonesia in 2011 - 2016 and currently there are 12 banks.

The method used in this study is quantitative data, because this study will analyze the problems that are realized with certain values. This study uses multiple regression analysis. Data processing will be carried out using IBM SPSS Statistics 25 software. 
RESULT

Table-1.1: Determinant Test $\left(\mathbf{R}^{2}\right)$

\begin{tabular}{|c|c|c|c|c|c|}
\hline \multicolumn{6}{|c|}{ Model Summary } \\
\hline Model & $\mathrm{R}$ & R Square & $\begin{array}{l}\text { Adjusted R } \\
\text { Square }\end{array}$ & $\begin{array}{l}\text { Std. Error of the } \\
\text { Estimate }\end{array}$ & Durbin-Watson \\
\hline 1 &, $514^{\mathrm{a}}$ & 265 & 199 & 217982,8879 & 1,296 \\
\hline \multicolumn{6}{|c|}{$\begin{array}{l}\text { a. Predictors: (Constant), Bad Debt Coverage Ratio, Capital Adequacy Ratio, Earning After Loss Loan } \\
\text { Provision, Non Performing Loan Ratio, Earning Before Loss Loan Provision }\end{array}$} \\
\hline \multicolumn{6}{|c|}{ b. Dependent Variable: DLLP } \\
\hline
\end{tabular}

Table 1.1 shows the $\mathrm{R}$ Square value of 0.265 or $26.5 \%$. This means that the Discretiaonary Loss Loan Provision can be explained by the Earning variable Before Loss Loan Provision, One year Ahead Earning,
Capital Adequacy Ratio, Non-Performing Loan Ratio and Bad Debt Coverage Ratio while the remaining 0.735 or $73.5 \%$ are explained by other factors that are not included in this research model.

Table-1.2: Test Result for Statistic F

\begin{tabular}{|c|c|c|c|c|c|c|}
\hline \multicolumn{7}{|c|}{ ANOVA $^{a}$} \\
\hline \multicolumn{2}{|c|}{ Model } & $\begin{array}{l}\text { Sum of } \\
\text { Squares }\end{array}$ & df & Mean Square & $\mathrm{F}$ & Sig. \\
\hline \multirow[t]{3}{*}{1} & Regression & $9,575 \mathrm{E}+11$ & 5 & $1,915 E+11$ & 4,030 &, $003^{b}$ \\
\hline & Residual & $2,661 \mathrm{E}+12$ & 56 & $4,752 \mathrm{E}+10$ & & \\
\hline & Total & $3,618 \mathrm{E}+12$ & 61 & & & \\
\hline \multicolumn{7}{|c|}{ a. Dependent Variable: DLLP } \\
\hline \multicolumn{7}{|c|}{$\begin{array}{l}\text { b. Predictors: (Constant), Bad Debt Coverage Ratio, Capital Adequacy Ratio, Earning } \\
\text { After Loss Loan Provision, Non Performing Loan Ratio, Earning Before Loss Loan } \\
\text { Provision }\end{array}$} \\
\hline
\end{tabular}

The ANOVA test data can be calculated using a $\mathrm{F}$ value of 4.030 with a probability of 0.003 . The probability value is much smaller than 0.05 so that it can be concluded that, Earning Before Loss Loan
Provision, One year Ahead Earning, Capital Adequacy Ratio, Non-Performing Loan Ratio and Bad Debt Coverage Ratio simultaneously (simultaneously) affect the Discretionary Loss Loan Provision.

Table-1.3: Test Result T

\begin{tabular}{|c|c|c|c|c|c|c|}
\hline \multicolumn{7}{|c|}{ Coefficients $^{a}$} \\
\hline \multirow[b]{2}{*}{ Mode } & & \multicolumn{2}{|c|}{ Unstandardized Coefficients } & \multirow{2}{*}{$\begin{array}{l}\text { Standardized } \\
\text { Coefficients } \\
\text { Beta }\end{array}$} & \multirow[b]{2}{*}{$t$} & \multirow[b]{2}{*}{ Sig. } \\
\hline & & B & Std. Error & & & \\
\hline \multirow[t]{6}{*}{1} & (Constant) & $-44781,730$ & 37417,566 & & $-1,197$ &, 236 \\
\hline & $\begin{array}{l}\text { Earning Before Loss } \\
\text { Loan Provision }\end{array}$ &, 196 &, 056 &, 572 & 3,529 &, 001 \\
\hline & $\begin{array}{l}\text { Earning After Loss Loan } \\
\text { Provision }\end{array}$ &, 242 &, 084 & ,458 & 2,893 &, 005 \\
\hline & Capital Adequacy Ratio & $-209283,462$ & 56374,715 &,- 724 & $-3,712$ &, 000 \\
\hline & $\begin{array}{l}\text { Non Performing Loan } \\
\text { Ratio }\end{array}$ & $-23403,245$ & 297163,340 &,- 011 &,- 079 &, 938 \\
\hline & Bad Debt Coverage Ratio & $-429464,409$ & 149616,299 &,- 423 & $-2,870$ &, 006 \\
\hline
\end{tabular}

\section{Furthermore, the results of the $t$ test in Table 1.3 can} be described as follows

a. The dependent variable of the Discretionary Loss Loan Provision shows that the constant value is 44,781,730 which means if the Earning variable Before Loss Loan Provision, Earning One Year ahead, Capital Adequacy Ratio, Non-Performing Loan Ratio and Bad Debt Coverage Ratio are considered constant, the
Discretionary dependent variable Loss Loan Provision will remain the same at $-44,781,730$.

b. The independent variable earning before Loss Loan Provision has a significant value of 0.001 with a constant value of 0.196 which means that it partially has a positive effect on the Discretionary Loss Loan Provision because the significant value is smaller than the probability value of 0.05 . That is because 
managers are indicated to have overestimated the potential amount of uncollectible loans for smooth income. In the study of Chang et al. [30] found the same results where there was a positive relationship between Earning before Loss Loan Provision and Discretionary Loss Loan Provision. And suggest that bank managers aim to increase the allowance for losses on accounts receivable to reduce bad debt and certainly will reduce Non Performing Loan Ratio.

c. The independent variable One Year a Head Earning has a significant value of 0.005 with a constant value of 0.242 which means that it partially has a positive effect on the Discretionary Loss Loan Provision because the significant value is smaller than the probability value of 0.05 . This is because the bank manager is indicated to have taken action to substantially increase the amount of loan loss provisions in the current year, which means that the number of loan losses will decrease significantly and does not cause an increase in profits next year.

In accordance with previous studies by Wahlen [18] indicating that when future cash flow plans increase, bank managers may increase the discretionary component of unexpected allowance for accounts receivable losses. Wahlen found a positive relationship between unexpected allowances and changes in future cash flows over the next three years.

And according to the research conducted by Chang et al. [30] where there is a positive relationship between One Year Ahead Earning and Discretionary Loss Loan Provision and it suggests that managers may use Loss Loan Provision to do Income Smoothing.

d. The independent variable Capital Adequacy Ratio has a significant value of 0,000 with a constant value of $-209,283,462$ which means that it partially has a negative effect on the Discretionary Loss Loan Provision because the significant value is smaller than the probability value of 0.05 .

In accordance with a previous study conducted by Collins et al. [25] suspect that the calculation of the main capital ratio indicates capital is increased by increasing allowance for losses on loans and / or lowering borrowing costs, and empirically found banks with low capital appear to reduce allowance for losses on accounts to consider the capital ratio. As where capital ratios play a very important role as an indicator to reflect the risk status of the bank itself, it indicates the ability of Islamic banks to survive under the current capital structure and interpret risks not to be seen as default.

Sharia bank managers indicated an increase in allowance for doubtful accounts to raise capital so that the Capital Adequacy Ratio will increase. Because the higher the CAR, the better the bank's ability to bear the risk of each risky credit/productive asset.

e. The independent variable Non Performing Loan Ratio has a significant value of 0.938 with a constant value of -23.403 .245 which means that partially does not affect the Discretionary Loss Loan Provision because the significant value is smaller than the probability value of 0.05 . That is because Indonesian banking has a non-performing loan that is relatively higher than conventional banks because it is not careful and selective in financing and the news about the high level of non-performing loans in Islamic banking is far greater than non-performing loans in conventional banking [4]. And the impact on the total credit generated is high enough so that the provision for reducing the ratio of Non-Performing Loan Ratio will be close to zero, and will not affect the Discretionary Loss Loan Provision.

This credit risk cannot be controlled by management because it can happen at any time without expectations by the company, for example the customer fails to pay off his debt in a timely manner, as a result the debt is categorized as non-performing loans and this will affect the value of Non-Loan Loan Ratio. The results of this study contradict the research conducted by Zahara [32].

But on the other hand the results of this study are in accordance with the research conducted by Chang et al. [30] where there is no relationship between Non Performing Loan Ratio and Discretionary Loss Loan Provision.

f. The independent variable Bad Debt Coverage Ratio has a significant value of 0.006 with a constant value of $-429,464.409$ which means that it partially has a negative effect on the Discretionary Loss Loan Provision because the significant value is smaller than the probability value of 0.05 . This is because the level of the ratio of uncollectible accounts reflects the attitude of bank managers to risk; banks with a higher ratio of uncollectible receivables remain the same policy for loans that cannot be collected. So the manager will try to keep the ratio of the problematic credit level still good.

But this is contrary to the research conducted by Chang et al. [30] where they found no relationship between Bad Debt Coverage Ratio and Discretionary Loss Loan.

\section{CONCLUSION}

Previous studies on loan provisions mainly focused on the effects of discretionary loan loss provisions on earnings management, capital management, tax management and stock returns. The author uses Islamic banking financial data for the period 
2011-2016 to investigate the factors that can affect the provision of loan losses. This finding provides evidence of a positive relationship between Discretionary Loss Loan Provision and Earning before Loss Loan Provision, One Year Ahead Earning, Non-Performing Loans and Bad Debt Coverage Ratio.

Furthermore, Based on the analysis of earnings management practices with the debt loss allowance approach using the Earning proxy Before Loss Loan Provision, One Year Ahead Earning, Capital Adequacy Ratio, Non-Performing Loan Ratio and Bad Debt Coverage Ratio in Islamic banking for 2011-2016 conclusions can be drawn as the following:

1. Earning Before Loss Loan Provision has a positive effect on the Discretionary Loss Loan Provision on Islamic Banks. This indicates that managers increase the allowance for losses on accounts receivable to reduce bad credit and reduce Non Performing Loan Ratio.

2. One Year ahead Earning has a positive effect on the Descretionary Loss Loan Provision on Islamic Banks. This is indicated by managers using the Discretionary Loss Loan Provision to do Income Smoothing.

3. Capital Adequacy Ratio has a negative effect on the Descretionary Loss Loan Provision in Islamic Banks. Because managers of Islamic banks are indicated to reduce the number of Discretionary Loss Loan Provision to raise capital so that the Capital Adequacy Ratio will increase.

4. Non-Performing Loan Ratio does not affect the Descretionary Loss Loan Provision at the Bank. This is because the impact on the total credit generated is high enough so that the provision for reducing the ratio of Non-Performing Loan Ratio will not close to the value of 0 (zero), and will not affect by reducing or increasing the number of Discretionary Loss Loan Provision.

5. Bad Debt Coverage Ratio negatively influences the Descretionary Loss Loan Provision at the Bank. This is indicated by managers of Islamic banking tend to reduce the number of Discretionary Loss Loan Provisions to increase operating profit so that it will increase Bad Debt Coverage Ratio

\section{REFFERENCE}

1. De Angelo, H., De Angelo, L., \& Rice, E. (1986). Going private: The effects of a change in ownership structure. In The Revolution in Corporate Finance. Blackwell Oxford.

2. Mulawarman, A. D. (2009). Akuntansi Syariah: Teori, Konsep dan Laporan Keuangan. Penerbit epublishing. Jakarta.
3. McNichols, M., \& Wilson, G. P. (1988). Evidence of earnings management from the provision for bad debts. Journal of accounting research, 1-31.

4. Ahmed, A. S., Takeda, C., \& Thomas, S. (1999). Bank loan loss provisions: a reexamination of capital management, earnings management and signaling effects. Journal of accounting and economics, 28(1), 1-25.

5. Bouvatier, V., \& Lepetit, L. (2008). Banks' procyclical behavior: Does provisioning matter?. Journal of international financial markets, institutions and money, 18(5), 513-526.

6. Chang, R. D., Shen, W. H., \& Fang, C. J. (2008). Discretionary loan loss provisions and earnings management for the banking industry. International Business \& Economics Research Journal (IBER), 7(3).

7. Niswander, F., \& Swanson, E. P. (2000). Loan, security, and dividend choices by individual (unconsolidated) public and private commercial banks. Journal of Accounting and Public Policy, 19(3), 201-235.

8. Altman, E. I., Brady, B., Resti, A., \& Sironi, A. (2005). The link between default and recovery rates: Theory, empirical evidence, and implications. The Journal of Business, 78(6), 22032228.

9. Kolari, J., \& Pynnönen, S. (2005). Event-study methodology: Correction for cross-sectional correlation in standardized abnormal return tests.

10. Mulawarman, A. D., \& Inyiak Ridwan M. (2006). Menyibak akuntansi syariah: rekonstruksi teknologi akuntansi syariah dan wacana ke aksi. Kreasi Wacana.

11. Sulaiman, M., \& Willett, R. J. (2001). Islam, economic rationalism and accounting. American Journal of Islamic Social Sciences, 18(2), 61-93.

12. Triyuwono, I. (2007). Mengangkat. Sing Liyan.

13. Mulya, H. (2012). Relasi antara akuntansi dan agama. Jurnal Ekonomi, Manajemen dan Akuntansi.

14. Graham, C., \& Neu, D. (2003, December). Accounting for globalization. In Accounting Forum. 27: 449-471

15. Moison, J. W. (2007). Chapter 47: Banks. Business Information, 's Gravenhage, 1333-1334.

16. Pérez, D., Salas-Fumás, V., \& Saurina, J. (2006). Earnings and capital management in alternative loan loss provision regulatory regimes (No. 0614).

17. Scott, William, R. (2009). Financial Accounting Theory. Fifth Edition. Canada Prentice Hall.

18. Healy, P.M., \& J.M. Wahlen. (1999). A review of the earnings management literature and its implications for standard setting. Accounting Horizon, 13(4): 365-383.

19. Chakravarthy, B. S. (1986). Measuring strategic performance. Strategic management journal, 7(5), 437-458. 
Ahmad Zaenal Ilham \& Wiwik Utami., Sch Bull, Jan 2020; 6(1): 16-25

20. McGuire, R. K., \& Mayer-Rosa, D. (Eds.). (1993). The practice of earthquake hazard assessment. International Association of Seismology and Physics of the Earth's Interior.

21. Jensen, M. C., \& Meckling, W. (1976). H.(1976). Theory of the firm: managerial behavior, agency costs and ownership structure En: Journal of Finance Economics, 3.

22. Wang, Z. L., \& Song, J. (2006). Piezoelectric nanogenerators based on zinc oxide nanowire arrays. Science, 312(5771), 242-246.

23. Demirkan, A., van Duijn, C. M., Ugocsai, P., Isaacs, A., Pramstaller, P. P., Liebisch, G., ... \& Kirichenko, A. V. (2012). Genome-wide association study identifies novel loci associated with circulating phospho-and sphingolipid concentrations. PLoS genetics, 8(2).

24. Beaver, W.H., \& E.E. Engel. (1996). Discretionary behavior with respect to allowance for loan losses and the behavior of securities prices. Journal of Accounting and Economics, 22(1-3): 177-206.

25. Collins, W. J. (1995). Collins COBUILD: English Dictionary. Harper Collins.

26. Moyer, S. E. (1990). Capital adequacy ratio regulations and accounting choices in commercial banks. Journal of Accounting and

Economics, 13(2), 123-154.

27. Beatty, A., Bin, K., \& Petroni, K.R. (2002). Earnings management to avoid earnings declines across publicly and privately held banks. Accounting Review, 77(3): 547-570.

28. Chen, L. X., Rajh, T., Wang, Z., \& Thurnauer, M. C. (1997). XAFS studies of surface structures of $\mathrm{TiO} 2$ nanoparticles and photocatalytic reduction of metal ions. The Journal of Physical Chemistry $B, 101(50), 10688-10697$.

29. Liu, D. (1985). Loess and the Environment. China Ocean Press.

30. Chang, S. J., Hsueh, T. J., Chen, I. C., \& Huang, B. R. (2008). Highly sensitive $\mathrm{ZnO}$ nanowire $\mathrm{CO}$ sensors with the adsorption of $\mathrm{Au}$ nanoparticles. Nanotechnology, 19(17), 1755

31. Sanusi, L. S. (2011). Banks in Nigeria and national economic development: a critical review, Central Bank of Nigeria.

32. Zahara, E., \& Kao, Y. T. (2009). Hybrid NelderMead simplex search and particle swarm optimization for constrained engineering design problems. Expert Systems with Applications, 36(2), 3880-3886. 